LETTERS

\title{
Successful treatment of refractory anterior scleritis in primary Sjögren's syndrome with rituximab
}

\author{
K Ahmadi-Simab, P Lamprecht, B Nölle, M Ai, W L Gross
}

Ann Rheum Dis 2005;64:1087-1088. doi: 10.1136/ard.2004.027128

A nterior scleritis is an inflammation of the superficial, subconjunctival sclera which may follow infection or occur in rheumatic disease. Anterior scleritis due to secondary immune complex mediated vasculitis is an extremely rare extraglandular manifestation in primary Sjögren's syndrome. ${ }^{1}$ Symptoms of anterior scleritis are pain, tearing, and photophobia. If left untreated, anterior scleritis may progress to scleromalacia and, ultimately, threaten eyesight by affecting the uvea. ${ }^{2}$ Here we report on the successful induction of remission with the B cell directed monoclonal anti-CD20 antibody in a case of refractory anterior scleritis with episcleritis in primary Sjögren's syndrome.

\section{CASE REPORT}

Primary Sjögren's syndrome was diagnosed in a 60 year old white woman according to the criteria of the European study group. ${ }^{3}$ Ocular and oral sicca symptoms included for more than 3 months, a pathological Schirmer test ( $<5 \mathrm{~mm} / 5 \mathrm{~min})$, and pathological salivary scintigraphy. Antinuclear antibodies and Ro (SSA) were detected and, later on, anti-fodrin antibodies. Complement levels were normal, cryoglobulin was negative. The patient was treated for arthralgia with low dose steroids and hydroxychloroquine.

In 2001 the patient's illness was complicated by an anterior scleritis. Treatment with steroids and eye drops containing ciclosporin was not effective. Application of different immunosuppressant drugs (methotrexate, ciclosporin, cyclophosphamide, intravenous immunoglobulin, tumour necrosis factor $\alpha$ blockade with infliximab, leflunomide) combined with high doses of steroids did not result in a remission of the anterior scleritis. Based on pathogenetic considerations (see below) we finally applied the monoclonal anti-CD20 antibody rituximab in order to induce remission and prevent the sequelae of anterior scleritis-that is, scleromalacia and uveitis.

Four weeks after stopping the preceding immunosuppression the patient was given rituximab for the first time. Four rituximab infusions ( $375 \mathrm{mg} / \mathrm{m}^{2}$ intravenously, MabThera) at 4 week intervals induced remission of the anterior scleritis (fig 1). The steroid dose could be tapered. Fluorescence activated cell sorting (FACS) analysis of lymphocyte populations showed a depletion of circulating peripheral B cells (fig 1). Thereafter, the patient received mycophenolate mofetil to maintain remission. She has now remained in remission for 6 months.

\section{DISCUSSION}

Killing of CD20 positive cells mediated by rituximab is caused by several mechanisms, including complement dependent cytotoxicity, antibody dependent cell mediated cytotoxicity, and induction of apoptosis. ${ }^{4}$ Rituximab induces remission of malignant B cell lymphomas. ${ }^{5}$ Clinical findings, data from animal models, and in vitro experiments suggest that B cells have a pivotal role in a number of rheumatic conditions such as rheumatoid arthritis and primary Sjögren's syndrome.
Rituximab successfully induced remission in a number of cases of refractory systemic lupus erythematosus, dermatomyositis, and cryoglubulinaemic vasculitis associated with hepatitis C virus..$^{6-8}$ An immunosuppressive combination treatment with rituximab also induces remission in refractory rheumatoid arthritis. ${ }^{9}$ B cells may play an important part in primary Sjögren's syndrome. Ectopic lymphoid tissue formation and lymphoproliferation are a hallmark of primary Sjögren's syndrome. The risk for malignant B cell lymphoma is increased nearly 40-fold in patients with Sjögren's syndrome. Alterations in the B cell compartment have been noted in primary Sjögren's syndrome. A significant reduction in circulating memory $\mathrm{CD} 27^{+} \mathrm{B}$ cells and accumulation of memory B cells in the salivary glands is seen in primary Sjögren's syndrome. ${ }^{10}$

These studies provided the rationale for the use of rituximab in our patient with refractory anterior scleritis in primary Sjögren's syndrome. We suggested that B cell depletion might favour induction of remission. To our knowledge this is the first report to show successful induction with rituximab in primary Sjögren's syndrome. We cannot totally rule out the possibility of delayed effects as a result of previous drug treatment, but induction of remission paralleled the complete depletion of circulating $\mathrm{B}$ cells induced by rituximab. Remission was subsequently maintained with mycophenolate mofetil in the presence of persistent peripheral B cell depletion.

Our report suggests that specific B cell depletion may be one successful strategy in the treatment of refractory primary Sjögren's syndrome. However, further studies are needed to determine the place of $\mathrm{B}$ cell depletion strategies in the treatment of severe organ manifestations in primary Sjögren's syndrome.

\section{Authors' affiliations \\ K Ahmadi-Simab, P Lamprecht, M Ai, W L Gross, Department of Rheumatology, University Hospital of Schleswig-Holstein, Campus Luebeck, and Rheumaklinik Bad Bramstedt, Ratzeburger Allee 160, 23538 Luebeck, Germany \\ B Nölle, Department of Ophthalmology, University Hospital of Schleswig-Holstein, Campus Kiel, Hegewischstr. 2, 24105 Kiel, Germany}

Correspondence to: Dr K Ahmadi-Simab; ahmadi@rheuma-zentrum.de

Accepted 28 December 2004

\section{REFERENCES}

1 Fox RI, Stern M, Michelson P. Update in Sjögren syndrome. Curr Opin Rheumatol 2000;12:391-8.

2 Sainz de la Maza M, Jabbur NS, Foster CS. Severity of scleritis and episcleritis. Ophthalmology 1994; 101:389-96.

3 Vitali C, Bombardieri S, Moutsopoulos HM, Balestrieri G, Bencivelli W, Bernstein RM, et al. Preliminary criteria for the classification of Siögren's syndrome. Results of a prospective concerted action supported by the European community. Arthritis Rheum 1993;36:340-7.

4 Golay J, Zaffaroni L, Vaccari T, Lazzari M, Borleri GM, Bernasconi S, et al. Biologic response of $B$ lymphoma cells to anti-CD20 monoclonal antibody 
A
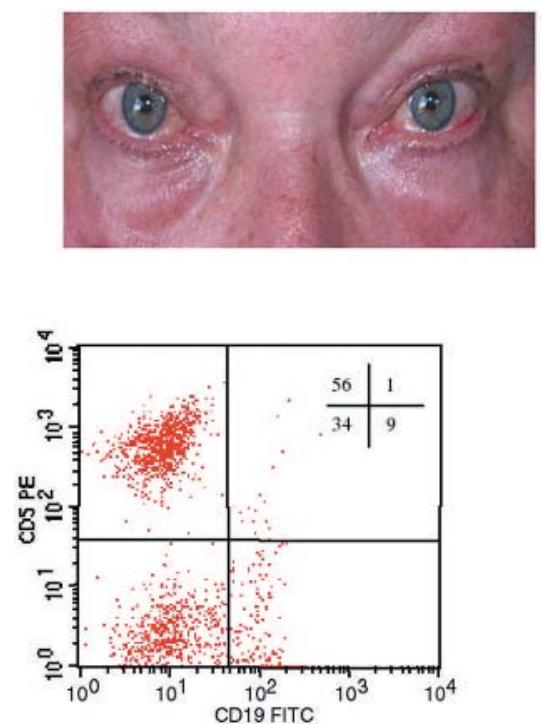

B After treatment
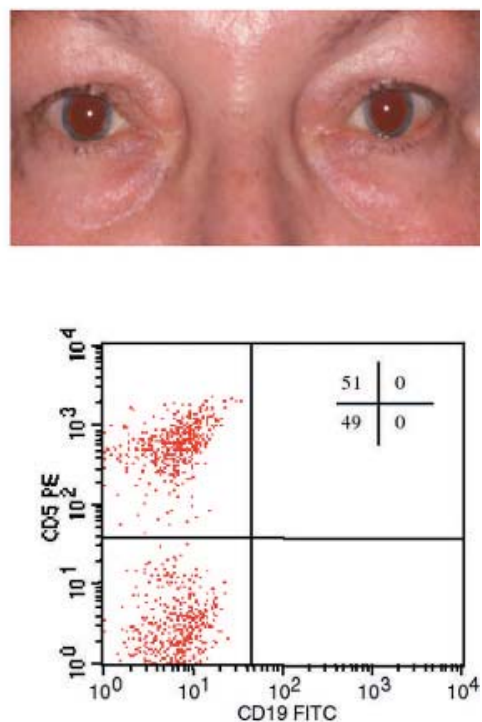

Figure 1 (A) Anterior scleritis and flow cytometric analysis of B cell population in primary Siögren's syndrome before treatment with the monoclonal anti-CD20 antibody rituximab. (B) Induction of remission with rituximab. For flow cytometric analysis peripheral blood mononuclear cells were stained with fluorochrome conjugated monoclonal antibodies for cell surface antigens or appropriate negative (isotype) controls. Four colour flow cytometric analysis was performed using a FACSCalibur flow cytometer (Becton Dickinson) and CELL-Quest software (Becton Dickinson). Lymphocytes were gated for analysis based on light scattering properties. A second gate was set based on light scattering properties and CD45 perCP staining properties. Positively and negatively stained populations were calculated by quadrant dot plot analysis determined by isotype controls. Quadrant markers were positioned to include $>99 \%$ of control (isotype) immunoglobulin stained cells in the lower left quadrant. The numbers given in the upper right quadrant of the FACS refer to the fraction of cells detected in each quadrant. B cells display CD19 expression. Before treatment about $10 \%$ of the circulating $\mathrm{CD} 19^{+} \mathrm{B}$ cell population belong to the $\mathrm{CD} 5^{+}$(B1) B cell fraction. After successful treatment with rituximab no circulating $\mathrm{CD} 19^{+} \mathrm{B}$ cells can be detected.

rituximab in vitro: CD55 and CD59 regulate complement-mediated cell lysis. Blood 2000:95:3900-8.

5 Coiffier B, Haioun C, Ketterer N, Engert A, Tilly H, Ma D, et al. Rituximab (anti-CD2O monoclonal antibody) for the treatment of relapsing or refractory aggressive lymphoma: a multicenter phase II study. Blood 1998:92:1927-1932

6 Leonardo MJ, Edwards JC, Cambridge G, Ehrenstein MR, Isenberg DA. An open study of $B$ lymphocyte depletion in systemic lupus erthemathosus. Arthritis Rheum 2002:46:2673-7.

7 Levine TD. A pilot study of rituximab therapy for refractory dermatomyositis [abstract]. Arthritis Rheum 2002;46(suppl):S488
8 Lamprecht $\mathbf{P}$, Lerin-Lozano C, Merz H, Dennin RH, Gause A, Voswinkel J, et al. Rituximab induces remission in refractory HCV-associated cryoglobulinemic vasculitis. Ann Rheum Dis 2003;62:1230-3

9 Cambridge G, Leandro MJ, Edwards JC, Ehrenstein MR, Salden M Bodman-Smith $M$, et al. Serologic changes following B lymphocyte depletion therapy for rheumatoid arthritis. Arthritis Rheum 2003;48:2146-54

10 Hansen A, Odendahl M, Reiter K, Jacobi AM, Feist E, Scholze J, et al. Diminished peripheral blood memory $B$ cells and accumulation of memory $B$ cells in the salivary glands of patients with Sjögren's syndrome. Arthritis Rheum 2002;46:2160-71.

\section{Granulomatous synovialitis with erosions in the shoulder joint: a rare case of polyarthritis caused by Mycobacterium kansasii}

\section{K Loddenkemper, C Enzweiler, C Loddenkemper, M Backhaus, G-R Burmester, F Buttgereit}

W present the rare case of a 60 year old man with Mycobacterium kansasii infection who complained of severe joint pain and swelling, predominantly of the right shoulder. Non-steroidal anti-inflammatory drugs (NSAIDs) led to pain relief. The swelling around the right shoulder was unsuccessfully treated by aspiration followed by surgery.

\section{CASE REPORT}

As a steam engine driver the patient was exposed to asbestos and inorganic dusts (coal, mineral/silicate). The rheumatological examination disclosed a mobile, firm, elastic swelling over the dorsal aspect of the left elbow, tenderness and mild swelling of both wrists, the metacarpophalangeal (MCP) joints, the third fingers of both hands, and the MCP joints of both thumbs. Joint effusion was palpated around the right shoulder and mobility was limited owing to pain. Inflammatory measures were raised and angiotensin converting enzyme was within normal range. No evidence of acid fast rods in the urine, the bronchial fluid, or aspirated joint fluid (right shoulder) was found. 


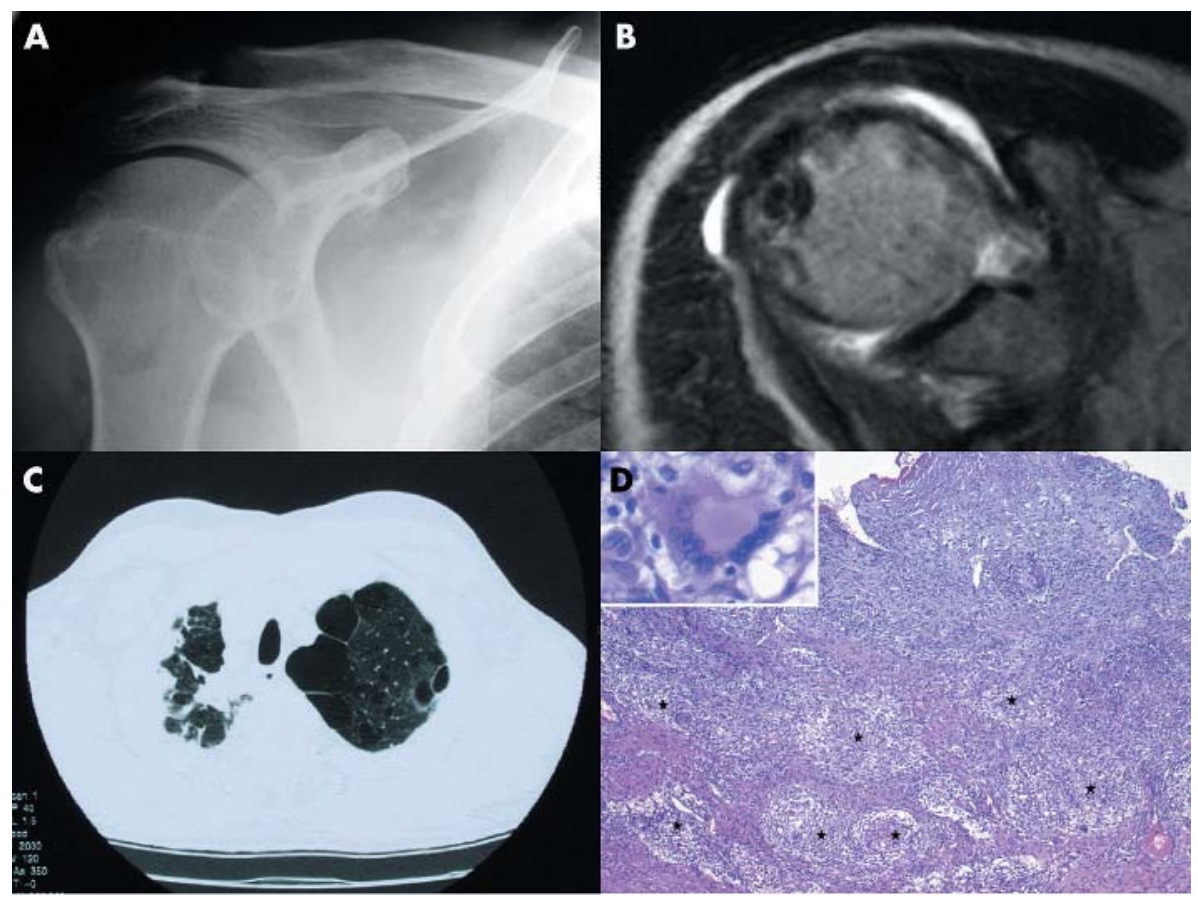

Figure 1 (A) A radiograph of the right shoulder joint showing erosive changes; (B) magnetic resonance imaging of the right shoulder showing marked erosive changes and profuse articular effusion; (C) high resolution computed tomography investigation of the thorax showing specific postinflammatory changes in the right upper lung field and bullae in the left upper field; (D) chronic fibrous synovialitis with multiple ill-defined epithelioid granulomas (stars); inset: Langhans' giant cell.

Table 1 Abnormal initial laboratory variables and autoantibodies

\begin{tabular}{|c|c|c|}
\hline Variables/autoantibodies & $\begin{array}{l}\text { Normal value } \\
\text { (test) }\end{array}$ & Patient's values \\
\hline ESR $(\mathrm{mm} / 1 \mathrm{st} h)$ & $<10 / 20$ & $58 / 78$ \\
\hline $\mathrm{C}$ reactive protein $(\mathrm{mg} / \mathrm{l})$ & $<5$ & 53.6 \\
\hline$\alpha_{2}$ Globulin (\%) & $6.3-10.5$ & 10.9 \\
\hline$\beta_{2}$ Globulin (\%) & $7.7-12.6$ & 13.2 \\
\hline Neutrophils (\%) & $50-70$ & 80.7 \\
\hline Lymphocytes (\%) & $25-40$ & 13.5 \\
\hline Platelets $\left(\times 10^{12} / \mathrm{I}\right)$ & $120-450$ & 468 \\
\hline Antinuclear antibodies & Negative & $\begin{array}{l}1 / 640 \text { (fine granular } \\
\text { cytoplasmic) }\end{array}$ \\
\hline $\begin{array}{l}\text { Anticardiolipin antibodies } \\
(\mathrm{lgG})(\mathrm{U} / \mathrm{ml})\end{array}$ & $<48$ (ELISA) & 305.5 \\
\hline Rheumatoid factors (IgM) (IU) & $<20$ (ELISA) & 47 \\
\hline Rheumatoid factors & $\begin{array}{l}\text { Negative (latex } \\
\text { test) }\end{array}$ & Negative \\
\hline $\begin{array}{l}\text { Circulating immune complexes } \\
(\mu \mathrm{g} / \mathrm{ml})\end{array}$ & $<55$ (Clq-ELISA) & 67 \\
\hline Borrelia antibody $\lg M$ & Negative (ELISA) & Negative \\
\hline Borrelia antibody lgG & Negative (ELISA) & Positive (42 units) \\
\hline
\end{tabular}

The radiographs and the magnetic resonance imaging findings (figs $\mathrm{IA}$ and $\mathrm{B}$ ) of the right shoulder showed erosions of the acromioclavicular joint and the humerus consistent with rheumatoid arthritis, as well as degenerative changes. Hands and elbows were radiologically normal.

Initially, because of a suspicion of pneumoconiosis and clinical signs of rheumatoid arthritis, the preferred diagnosis was Caplan's syndrome-a form of rheumatoid arthritis marked by the intercurrent onset of polyarthritis and pneumoconiosis (usually silicosis), but $x$ ray examination and computed tomography of the thorax showed postinflammatory changes in the right upper lung field, bullae in the left lung, and pleural thickening with characteristic asbestos related plaques without signs of silicosis (fig IC).

Histology displayed ill-defined epithelioid granulomas and chronic fibrous synovialitis (fig lD), therefore sarcoidosis was also considered but thought unlikely in view of an unremarkable CD4/CD8 ratio in the bronchial fluid, normal angiotensin converting enzyme values, and the absence of small joint involvement.

In the presence of undifferentiated autoantibody phenomena and raised inflammatory variables (table 1) without convincing evidence for sarcoidosis or acute tuberculosis, early undifferentiated connective tissue disease was diagnosed and treatment with azathioprine and prednisolone was started under isoniazid cover (considering a positive Multimerieux tuberculin test).

Surprisingly, after three weeks Mycobacteria were cultured in the fluid from the right shoulder and characterised as $M$ kansasii (16S rRNA gene sequencing). As recommended, the patient was prescribed a triple combination of isoniazid (300 mg/daily), rifampicin (600 mg/daily), and ethambutol $(3 \times 500 \mathrm{mg} /$ daily) for 18 months and the firm swelling around the left elbow and autoantibody phenomena resolved completely. Azathioprine was discontinued, prednisolone reduced.

Today ( 2 years after completing treatment) the patient reports occasional arthralgia of the shoulder joints, interpreted as degenerative changes and responding to NSAIDs.

\section{DISCUSSION}

M kansasii was first described by Buhler and Pollack in 1953. Infections with $M$ kansasii are environmentally acquired. Interestingly, $M$ kansasii is primarily restricted to tap water and can survive for up to 12 months. ${ }^{12}$ Usually $M$ kansasii affects the lungs similarly to tuberculosis and rarely affects joints, tendons or bone. ${ }^{34}$

Among the non-tuberculous Mycobacteria, $M$ kansasii is the commonest cause of monarthritis, usually exhibiting erosive 
changes. ${ }^{5}{ }^{6}$ Tests for acid fast rods in synovial fluid are often negative. Overall, only 50 cases of $M$ kansasii arthritis have been described during the past 40 years. About one half of the patients had underlying disorders (for example, HIV, rheumatic diseases), and for some a previous joint puncture (iatrogenic infection) or trauma may be suspected as the probable route of entry. ${ }^{3}$ In the case described here, the infection had been preceded by punctures of the shoulder joint, although haematogenic spread cannot be ruled out completely because of postinflammatory changes in the right upper lobe.

In conclusion, care must be taken not to overlook an infection with atypical Mycobacteria in polyarthritis with erosive changes.

\author{
Authors' affiliations \\ K Loddenkemper, M Backhaus, G-R Burmester, F Buttgereit, \\ Department of Rheumatology and Clinical Immunology, University \\ Medicine Berlin Charité University Hospital, Schumannstrasse 20-21, \\ 10117 Berlin, Germany \\ C Enzweiler, Department of Radiology, University Medicine Berlin, \\ University Hospital Charité, Schumannstrasse 20-21, 10117 Berlin, \\ Germany
}

C Loddenkemper, Institute of Pathology, University Hospital Charité, University Medicine Berlin, Campus Benjamin Franklin, Hindenburgdamm 30, 12200 Berlin, Germany

Correspondence to: Dr K Loddenkemper, konstanze.loddenkemper@ charite.de

Accepted 28 December 2004

\section{REFERENCES}

1 Steadham JE. High-catalase strains of Mycobacterium kansasii isolated from water in Texas. J Clin Microbiol 1980;11:486-98.

2 Zhang Y, Mann LB, Wilson RW, Brown-Elliot BA, Vincent V, linur Wallace RJJ. Molecular analysis of Mycobacterium kansasii isolates from the United States. J Clin Microbiol 2004:42:119-25.

3 Bernard L, Vincent V, Lortholary O, Raskine L, Vettier C, Colaitis D, et al. Mycobacterium kansasii septic arthritis: French retrospective study of 5 years and review. Clin Infect Dis 1999;29:1455-60.

4 Richter R, Hahn H, Nubling W, Kohler G. [Shoulder girdle and shoulder joint tuberculosis. ] Z Rheumatol, 1985;44:87-92.

5 Girard DE, Bagby GC Jr, Walsh JR. Destructive polyarthritis secondary to Mycobacterium kansasii. Arthritis Rheum 1973;16:665-9.

6 Iwata H, Kinoshita M, Sumiya M, Iwai A, Aotsuka S, Hirata D, et al. Emergence of erosive polyarthritis coincident with Mycobacterium kansasii pulmonary infection in a patient with systemic sclerosis-rheumatoid arthritis overlap syndrome. Clin Exp Rheumatol 1999;17:757-8.

\section{Etanercept in treatment of Felty's syndrome A Ghavami, S Genevay, T Fulpius, C Gabay}

$\mathrm{F}$ elty's syndrome (FS) is an uncommon extra-articular manifestation of rheumatoid arthritis (RA). It is more prevalent among women around 60 with a long history of severe articular disease, positive rheumatoid factor, and who carry the HLA-DR4 allele. ${ }^{1}$ Felty's syndrome has a poor prognosis, with an increased mortality due to a higher incidence of severe infection. ${ }^{2}$ We describe a patient with seropositive, erosive RA and history of extra-articular manifestations, including vasculitis and FS. Treatment with etanercept gradually decreased the neutrophil count over 20 months. Discontinuation of etanercept and initiation of methotrexate was followed by a dramatic and sustained improvement of neutrophil count.

\section{CASE REPORT}

A 75 year old white woman with a 19 year history of seropositive RA with extra-articular manifestations including mononeuritis multiplex (1998) and at least a 4 year history of FS (idiopathic neutropenia reported since 1994 and splenomegaly described on abdominal ultrasonography since 1999) was followed up at the Division of Rheumatology at the Geneva University Hospital.

She was treated with azathioprine and prednisone and had a mean white blood cell (WBC) count of $2.0 \times 10^{9} / 1$ (ranging from 1.6 to $2.7 \times 10^{9} / 1$ ) and absolute neutrophil count (ANC) of $1.4 \times 10^{9} / 1$ (ranging from 1.1 to $2.2 \times 10^{9} / 1$ ) since May 1999 . In October 2000 treatment with azathioprine was decreased and replaced by etanercept $25 \mathrm{mg}$ (twice a week, subcutaneously) due to synovitis, morning stiffness, and biological signs of inflammation. Improvement in morning stiffness and synovitis was noted, with a decrease of the mean erythrocyte sedimentation rate and $\mathrm{C}$ reactive protein. Prednisone was tapered to 5-7.5 mg daily. During the treatment with etanercept the patient had one infectious complication (right knee septic arthritis in February 2001). Treatment with azathioprine was then discontinued.
Despite the improvement of inflammatory articular manifestations, the WBC count and ANC decreased during a 14 month follow up, resulting in a total WBC count of $1.6 \times 10^{9} / 1$ and an ANC of $0.3 \times 10^{9} / 1$ (fig 1). Haematological disorders were excluded by flow cytometry. Treatment with etanercept was discontinued and replaced by oral methotrexate $10 \mathrm{mg}$ and folic acid $5 \mathrm{mg}$ weekly. The WBC count and ANC increased immediately to achieve a normal range (ANC $\left.>2.0 \times 10^{9} / 1\right)$ within 3 months. The initial dose of methotrexate was increased from $10 \mathrm{mg}$ to $12.5 \mathrm{mg}$ weekly owing to wrist synovitis, with subsequent improvement of articular inflammation. A 2 year follow up shows that the WBC count stabilised.

\section{DISCUSSION}

In this patient with seropositive, erosive RA and extraarticular manifestations, administration of etanercept resulted in progressive neutropenia. Discontinuation of etanercept and initiation of methotrexate was associated with a dramatic increase in the WBC count and ANC.

Systemic immunosuppressive treatment is considered to be the most appropriate form of treatment for FS. Experience with cyclophosphamide, ciclosporin, azathioprine, or leflunomide in FS is limited. ${ }^{3}$ Methotrexate is usually effective in FS. Low dose oral pulse therapy results in improvement in most patients. ${ }^{5}{ }^{6}$

Although articular inflammation in our patient responded well to etanercept, a threatening decrease in the WBC count and ANC occurred. The exact mechanism of this observation remains unclear. On the basis of a few reports on pancytopenia and aplastic anaemia after etanercept treatment, ${ }^{7}$ a direct effect of etanercept on the WBC count cannot be ruled out completely. Natural evolution of FS might also be postulated. However, the rapid increase of the WBC count and ANC after the introduction of methotrexate and the sustained effect during the following years does not support 


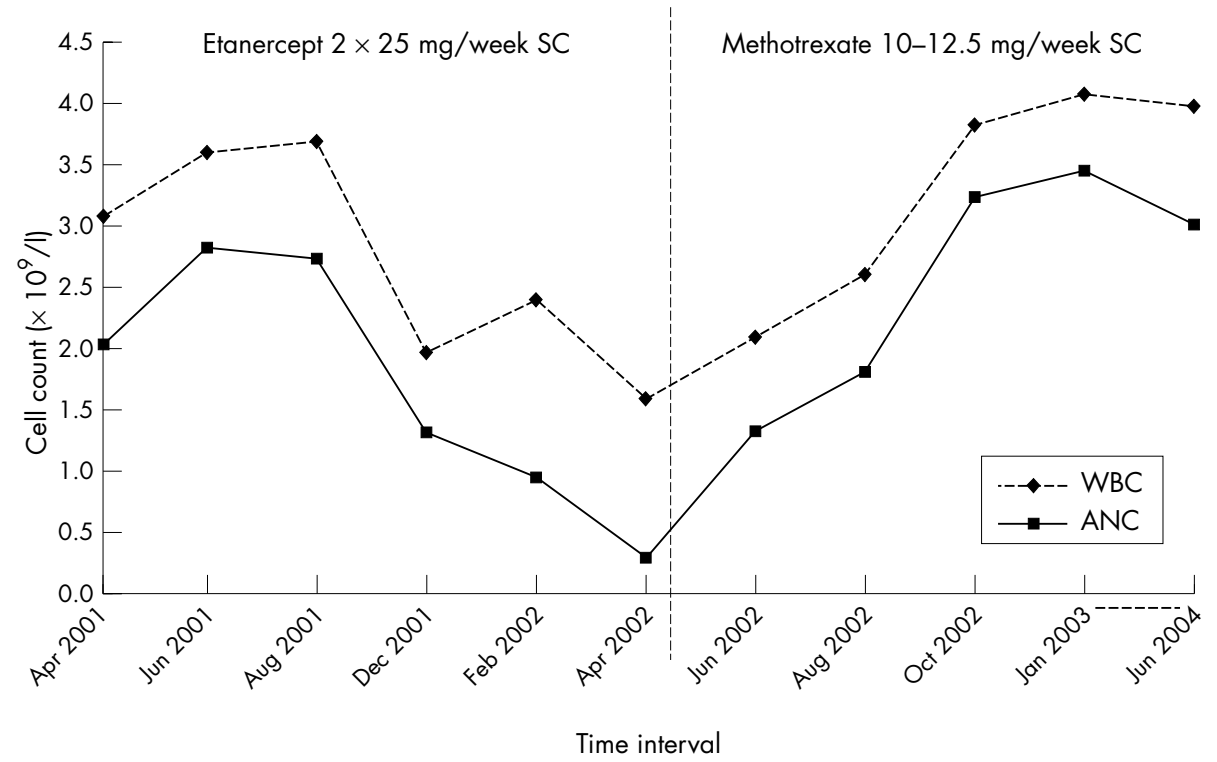

Figure 1 After the introduction of etanercept, the white blood cells (WBC) and the absolute neutrophil count (ANC) decreased progressively to neutropenic levels. This was reversed by changing treatment to methotrexate.

this hypothesis. Finally, a lack of efficacy of etanercept in controlling FS must also be considered. This possibility is supported by a recent report on the lack of efficacy of etanercept on FS in a patient with RA and secondary amyloidosis. ${ }^{8}$ At present, we call for caution when etanercept is used for patients with FS.

\section{Authors' affiliations}

A Ghavami, S Genevay, T Fulpius, C Gabay, Division of Rheumatology, Geneva University Hospital, Switzerland

Correspondence to: Professor C Gabay, Division of Rheumatology, Geneva University Hospital, 26 av. Beau-Séjour, 1211 Genève 14, Switzerland; cem.gabay@hcuge.ch

Accepted 19 December 2004

\section{REFERENCES}

1 Sibley JT, Haga M, Visram DA, Mitchell DM. The clinical course of Felty's syndrome compared to matched controls. J Rheumatol 1991;18:1163-7.

2 Thorne C, Urowitz MB. Long-term outcome in Felty's syndrome. Ann Rheum Dis 1982;41:486-9.

3 Wiesner KB, Shapiro RF, Bryan BL, Fuller C, Utsinger PD. Immunosuppressive therapy in Felty's syndrome. N Engl J Med 1977;296:1172.

4 Talip F, Walker N, Khan W, Zimmermann B. Treatment of Felty's syndrome with leflunomide. J Rheumatol $2001 ; 28: 868-70$.

5 Wassenberg S, Herborn G, Rau R. Methotrexate treatment in Felty's syndrome. Br J Rheumatol 1998;37:908-11.

6 Tan N, Grisanti MW, Grisanti JM. Oral methotrexate in the treatment of Felty's syndrome. J Rheumatol 1993;20:599-601.

7 Kuruvilla J, Leitch HA, Vickars LM, Galbraith PF, Li CH, Al-Saab S, et al. Aplastic anemia following administration of a tumor necrosis factor-alpha inhibitor. Eur J Haematol 2003;71:396-8.

8 Ravindran J, Shenker N, Bhalla AK, Lachmann H, Hawkins P. Case report: Response in proteinuria due to AA amyloidosis but not Felty's syndrome in a patient with rheumatoid arthritis treated with TNF-alpha blockade. Rheumatology (Oxford) 2004;43:669-72.

\section{Positron emission tomography use in the diagnosis and follow up of Takayasu's arteritis}

D Moreno, J R Yuste, M Rodríguez, M J García-Velloso, J Prieto

Ann Rheum Dis 2005;64:1091-1093. doi: 10.1136/ard.2004.029561

$\mathrm{T}$ kayasu's arteritis (TA) is an uncommon chronic vasculitis of unknown origin that affects large and medium sized arteries, especially the aorta, its branches and pulmonary arteries. ${ }^{12}$ TA may present as fever of unknown origin (FUO), ${ }^{3}$ and inflammatory cells have been shown to take up $\left[{ }^{18} \mathrm{~F}\right]$ fluorodeoxyglucose $\left(\left[{ }^{18} \mathrm{~F}\right] \mathrm{FDG}\right)$ avidly. ${ }^{4-6}$

\section{CASE REPORTS}

\section{Patient 1}

A 27 year old woman was admitted for FUO, headache, and interscapular pain, radiating to the neck and shoulders in the past 2 months. Physical and vascular examinations were normal. Laboratory tests showed anaemia (haemoglobin $84 \mathrm{~g} / \mathrm{l}$ ) and a raised erythrocyte sedimentation rate (ESR $79 \mathrm{~mm} / \mathrm{lst} \mathrm{h}$ ). Blood cultures, a Venereal Disease Research Laboratory (VDRL) test, and autoimmune serological findings were negative. Vascular magnetic resonance (VMR) was normal. $\left[{ }^{18} \mathrm{~F}\right]$ FDG positron emission tomography $\left(\left[{ }^{18} \mathrm{~F}\right] \mathrm{FDG}-\right.$ PET) showed hypermetabolism in the brachiocephalic trunk, left carotid artery, and thoracic aorta (fig 1A).

Treatment was started with methylprednisolone ( $1 \mathrm{mg} / \mathrm{kg} /$ day; $60 \mathrm{mg}$ ) and methotrexate (15 mg/week). The pain disappeared quickly after starting treatment. At 7 months of follow up the patient remained asymptomatic. Laboratory tests improved (haemoglobin $110 \mathrm{~g} / \mathrm{l}$; ESR $8 \mathrm{~mm} / \mathrm{lst} \mathrm{h}$ ). 

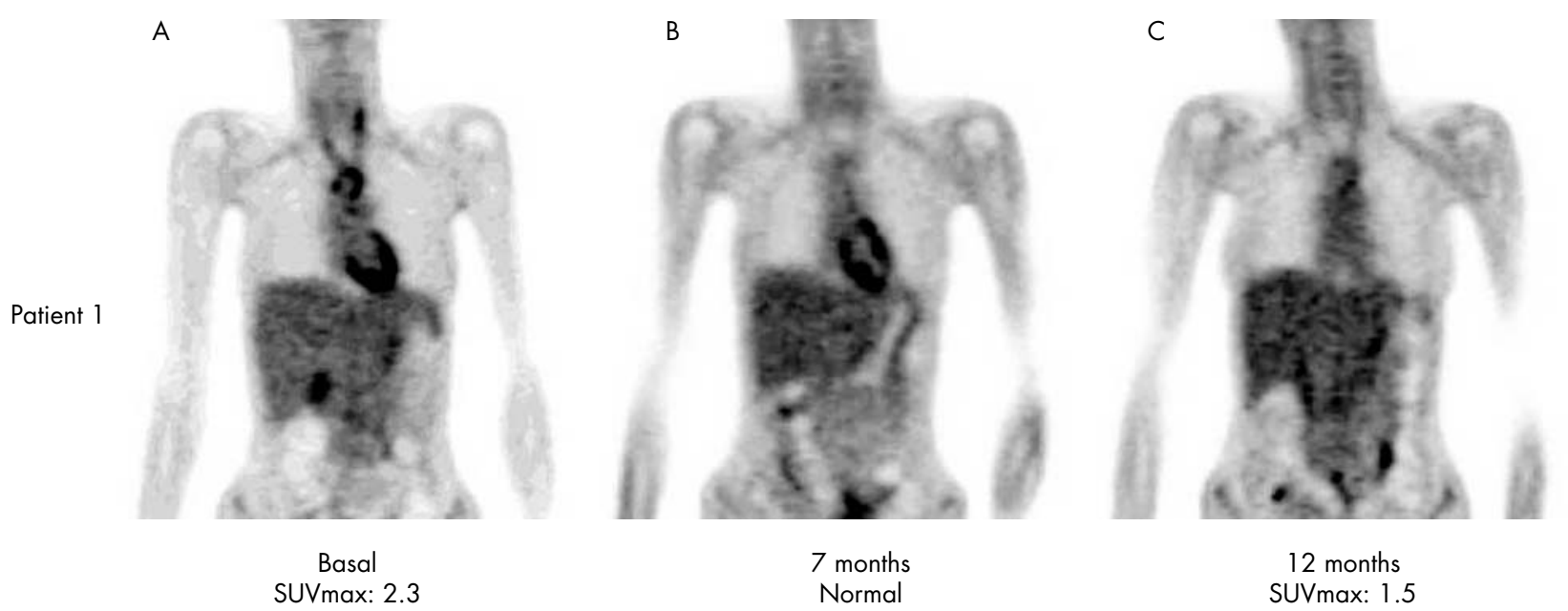

Figure 1 (A) Hypermetabolism is detected in the brachiocephalic trunk, left carotid artery, and thoracic aorta. (B) Normal thoracic metabolism (unspecific bowel uptake can be seen in the abdominal area). (C) Hypermetabolism is detected in the aortic arch and the proximal third of both carotid arteries.

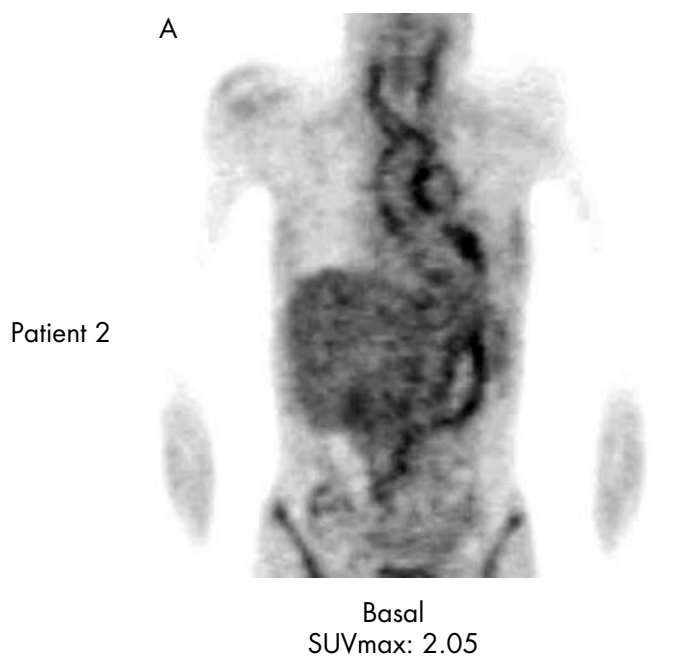

SUVmax: 2.05

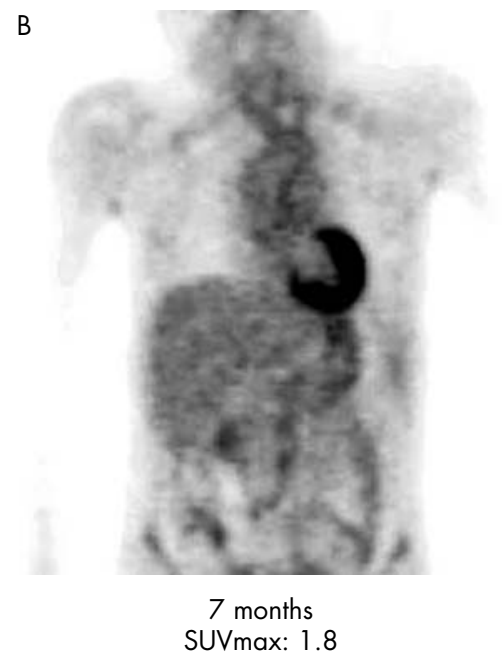

Figures 2 ( $A$ and $B$ ) PET shows metabolism in the thoracic aorta, carotids, brachiocephalic trunk and pulmonary trunk. $\left[{ }^{18} \mathrm{~F}\right]$ FDG metabolism was normal (fig $1 \mathrm{~B}$ ). When the methylprednisolone dose was reduced below $16 \mathrm{mg} / \mathrm{day}$, the pain reappeared in the left cervical zone, upper chest, and back. The ESR was higher ( $16 \mathrm{~mm} / \mathrm{lst} \mathrm{h})$ and $\left[{ }^{18} \mathrm{~F}\right] \mathrm{FDG}-\mathrm{PET}$ showed hypermetabolism again, matching the painful zones (fig 1C).

\section{Patient 2}

A 21 year old woman presented with FUO within the past year and neck pain radiating to the left shoulder within the past month. Physical examination showed a thrill in the right supraclavicular fossa, but no bruits were detected. Upper limbs pulses were normal. Laboratory tests showed anaemia (haemoglobin $80 \mathrm{~g} / \mathrm{l}$ ) and a raised ESR ( $72 \mathrm{~mm} / \mathrm{lst} \mathrm{h}$ ). Blood cultures, VDRL test, and autoimmune serological findings were negative. VMR was normal. $\left[{ }^{18} \mathrm{~F}\right]$ FDG-PET showed hypermetabolism in the thoracic aorta, carotids, brachiocephalic trunk, and pulmonary trunk (fig 2A).

Treatment was started with methylprednisolone $(1 \mathrm{mg} / \mathrm{kg} /$ day; $60 \mathrm{mg}$ ) and methotrexate ( $15 \mathrm{mg} /$ week), with fast clinical and biochemical response. At 4 months of follow up she remained asymptomatic, but radial pulse and blood pressure were undetectable in the left arm. Doppler ultrasonography showed brachial artery thrombosis with collateral neovasculature. Laboratory tests showed haemoglobin $110 \mathrm{~g} / \mathrm{l}$ and ESR $11 \mathrm{~mm} / \mathrm{lst} \mathrm{h}$. The dose of methylprednisolone was maintained at $30 \mathrm{mg} /$ day. No other symptoms appeared until 3 months later, when methylprednisolone was reduced to $20 \mathrm{mg} /$ day. She presented with upper thoracic pain and weakness in both arms. Haemoglobin was $111 \mathrm{~g} / \mathrm{l}$ but ESR was $77 \mathrm{~mm} / \mathrm{lst} \mathrm{h}$. $\left[{ }^{18} \mathrm{~F}\right]$ FDG-PET showed significant inflammatory activity (fig 2B).

\section{DISCUSSION}

$\left[{ }^{18} \mathrm{~F}\right] \mathrm{FDG}$-PET has been shown to be a useful diagnostic tool in $\mathrm{FUO}^{7}$ and in some types of vasculitis, ${ }^{45}$ including TA. ${ }^{6}{ }^{8}$ It allows an early diagnosis of $\mathrm{TA}^{8}$ during the inflammatory or "pre-pulseless" phase, ${ }^{12}$ when other techniques such as VMR or arteriography may be normal. This point is crucial because the "pre-pulseless" phase will not fulfil the American College of Rheumatology criteria for TA, which are mostly based on advanced disease. ${ }^{1}$ An early diagnosis allows early treatment and, theoretically, it might reduce the risk of complications.

Moreover, $\left[{ }^{18} \mathrm{~F}\right]$ FDG-PET can identify more vascular regions affected by the inflammatory process than $\mathrm{VMR}^{5}$ 
and quantify the inflammatory activity of the disease. ${ }^{6}$ This is important, because $44 \%$ of patients in clinical remission have histologically proven inflammatory activity ${ }^{12}$ and blood inflammatory markers are still limited.' In addition, $\left[{ }^{18} \mathrm{~F}\right]$ FDG-PET is useful in assessing the effectiveness of different treatments during follow up ${ }^{6}$ and could be used in randomised controlled trials. However, $\left[{ }^{18} \mathrm{~F}\right]$ FDG-PET should be compared with more standardised techniques, such as angiography, VMR, computed tomography, or Doppler ultrasound to obtain firm support for its value in clinical practice.

The accuracy of $\left[{ }^{18} \mathrm{~F}\right] \mathrm{FDG}$-PET for diagnosing TA has been estimated as $94 \%$ and false positives are not found in normal patients aged under $40 .{ }^{6}$ In our patients PET was the only technique with a positive result for diagnosing TA and showed good correlation with disease activity. Our experience also confirms previous reports of relapsing TA after tapering the corticoid dose, ${ }^{29}$ even though methotrexate was started after diagnosis.

\section{Authors' affiliations}

D Moreno, J R Yuste, J Prieto, Department of Internal Medicine, Clinica Universitaria de Navarra, University of Navarra, Pamplona, Spain M Rodríguez, M J García-Velloso, Department of Nuclear Medicine, Clinica Universitaria de Navarra, University of Navarra, Pamplona, Spain
Correspondence to: Dr J R Yuste, Department of Internal Medicine, Clinica Universitaria de Navarra. University of Navarra, Avda Pio XII, 36, 31080. Pamplona, Spain; iryuste@unav.es

Accepted 28 December 2004

\section{REFERENCES}

1 Kerr GS, Hallahan CW, Giordano J, Leavitt RY, Fauci AS, Rottem M, et al. Takayasu arteritis. Ann Intern Med 1994;120:919-29.

2 Johnston SL, Lock RJ, Gompels MM. Takayasu arteritis: a review. J Clin Pathol 2002;55:481-6.

3 Uthman IW, Bizri AR, Haij Ali RA, Nasr FW, Khalil IM. Takayasu's arteritis presenting as fever of unknown origin: report of two cases and literature review. Semin Arthritis Rheum 1999:28:280-5.

4 Bleeker-Rovers CP, Bredie SJ, van der Meer JW, Corstens FH, Oyen WJ. Fluorine 18 fluorodeoxyglucose positron emission tomography in the diagnosis and follow-up of three patients with vasculitis. Am J Med 2004;116:50-3.

5 Belhocine T, Blockmans D, Hustinx R, Vandevivere J, Mortelmans L. Imaging of large vessel vasculitis with (18)FDG PET: illusion or reality? A critical review of the literature data. Eur J Nucl Med Mol Imaging 2003;30:1305-13.

6 Webb M, Chambers A, AL-Nahhas A, Mason JC, Maudlin L, Rahman L, et al. The role of (18)F-FDG PET in characterising disease activity in Takayasu arteritis. Eur J Nucl Med Mol Imaging 2004;31:627-34 [Epub 17 January 2004]

7 Mourad O, Palda V, Detsky AS. A comprehensive evidence-based approach to fever of unknown origin. Arch Intern Med 2003;163:545-51

8 Kissin EY, Merkel PA. Diagnostic imaging in Takayasu arteritis. Curr Opin Rheumatol 2004;16:31-7.

9 Matsuyama A, Sakai N, Ishigami M, Hiraoka H, Kashine S, Hirata A, et al. Matrix metalloproteinases as novel disease markers in Takayasu arteritis. Circulation 2003;108:1469-73.

\section{Interleukin (IL) $1 \alpha$, IL $1 \beta$, IL receptor antagonist, and IL10 polymorphisms in psoriatic arthritis}

\section{Peddle, C Butt, T Snelgrove, P Rahman}

lis nterleukin (IL) $\mathrm{l}$ is a potent proinflammatory cytokine that occurs as ILl $\alpha$ and ILl $\beta$. The biological activity of ILl $\alpha$ and ILl $\beta$ is initiated by binding with type I ILl receptor and is inhibited by ILl receptor antagonist (ILRa). ${ }^{1}$ IL10 is an antiinflammatory cytokine that suppresses macrophage production of cytokines and enhances soluble cytokine receptor release. $^{2}$ These cytokines have been implicated in the pathogenesis of psoriatic arthritis (PsA), as increased expression of ILl and IL10 has been observed in the synovial fluid and synovial membrane of patients with PsA in comparison with patients with osteoarthritis. ${ }^{3}$ Given the proposed function of these cytokines in autoimmune disease, we set out to examine the role of polymorphisms in ILl $\alpha$, ILI $\beta$, ILRa, and IL10 in the Newfoundland PsA population.

This study was approved by the ethics committee at the Memorial University of Newfoundland. In this study, PsA was defined as an inflammatory arthritis in patients with psoriasis and the absence of other causes for inflammatory arthritis. Patients and controls were genotyped for the following single nucleotide polymorphisms (SNPs): ILl $\alpha$ $(-889 ;$ rsl143634), ILl $\beta$ (+3953; rs1800587), and ILl0 (-1082; rs1800896) using the Sequenom MassArray platform. All primers were designed using SpectroDESIGNER software. For ILRa (accession No AF387734), an 86 bp variable number tandem repeat was determined by a polymerase chain reaction.

Two hundred and twenty six patients with PsA and 95 matched controls were studied. The mean age of the patients with PsA was 54.0 years; 108 (48\%) were women. All genotypes satisfied the Hardy-Weinberg equilibrium. $\chi^{2}$ Tests were used to examine the relationship between the minor allele frequencies of the candidate genes and PsA. The minor allele frequencies for patients with PsA and controls were for ILl $\alpha(\mathrm{T}) 0.24 v 0.31$ (odds ratio 0.7 (95\% confidence interval 0.4 to 1.2$))$ respectively; for $\operatorname{ILl} \beta(\mathrm{T}) 0.24 v 0.25(0.9$ (0.5 to 1.6$)$ ); for ILRa (two repeats) $0.27 v 0.24$ ( 1.1 ( 0.7 to 2.0)); and for IL10 (A) $0.47 v 0.49(0.9$, (0.5 to 1.6)). Thus none of the polymorphisms examined were significantly associated with PsA in the Newfoundland population.

There is a paucity of association studies of ILl and IL10 in PsA. In studies with an admixed white population Ravindran et al noted an increased frequency of the ILl $\alpha-889$ polymorphism among patients with PsA but observed no difference for ILl $\beta+3953$ and ILl receptor Rl +970 genes. ${ }^{4}$ Another study demonstrated no association between ILl $\beta$ +3953 and ILIRa gene polymorphisms in patients with PsA nor with IL10 SNPs $(-1082$ and -592$)$ and PsA. ${ }^{5}$

Newfoundland has a white founder population known to exhibit homogeneity comparable to that of the Hutterites. ${ }^{6} \mathrm{~A}$ potential advantage in studying this population is the detection of small to modest genetic effects, as a result of an enhanced signal to noise ratio. In our study no association was found between polymorphisms in ILl $\alpha(-889)$, ILl $\beta$ $(+3953)$, ILl0 (-1082), and ILRa in the Newfoundland founder population. Thus, these polymorphisms are unlikely to have a major role in the Newfoundland PsA population. 
We cannot, however, rule out the possibility that an association with other SNPs exists in these genes. Furthermore, we also acknowledge that because our sample size is limited we are unlikely to detect small differences in allele frequencies.

\section{Authors' affiliations \\ L Peddle, C Butt, T Snelgrove, P Rahman, Memorial University of Newfoundland, St Clare's Mercy Hospital, Memorial University of Newfoundland, St John's Newfoundland, Canada}

Correspondence to: Dr P Rahman, St Clare's Mercy Hospital, 1 South 154 LeMarchant Rd, St John's, Newfoundland, Canada A1C-5B8; prahman@mun.ca

Accepted 15 December 2004

\section{REFERENCES}

1 Nicklin MJ, Barton JL, Nguyen M, FitzGerald MG, Duff GW, Kornman K. A sequence-based map of the nine genes of the human interleukin-1 cluster. Genomics 2002;79:718-25.

2 Mclnnes IB, Illei GG, Danning CL, Yarboro CH, Crane M, Kuroiwa T, et al. IL10 improves skin disease and modulates endothelial activation and leukocyte effector function in patients with psoriatic arthritis. J Immunol 2001;167:4075-82.

3 Partsch G, Steiner G, Leeb BF, Dunky A, Broll H, Smolen JS. Highly increased levels of tumor necrosis factor-alpha and other proinflammatory cytokines in psoriatic arthritis synovial fluid. J Rheumatol 1997;24:518-23

4 Ravindran JS, Owen P, Lagan A, Lewis J, Korendowych E, Welsh K, et al. Interleukin $1\{$ alpha\}, interleukin $1\{$ beta\} and interleukin 1 receptor gene polymorphisms in psoriatic arthritis. Rheumatology (Oxford) 2004;43:22-6

5 Balding J, Kane D, Livingstone W, Mynett-Johnson L, Bresnihan B, Smith O, et al. Cytokine gene polymorphisms: association with psoriatic arthritis susceptibility and severity. Arthritis Rheum 2003;48:1408-13.

6 Bear JC, Nemec TF, Kennedy JC, Marshall WH, Power AA, Kolonel VM, et al. Inbreeding in outport Newfoundland. Am J Med Genet 1988;29:649.

\title{
Production of anti-CCP antibodies and matrix metalloproteinase-3 by human rheumatoid arthritis synovial tissues using SCID mice
}

\author{
S Iwaki-Egawa, H Matsuno, Y Ogawa, Y Watanabe
}

Ann Rheum Dis 2005;64:1094-1095. doi: 10.1136/ard.2004.032847

$\mathrm{T}$ he diagnosis of rheumatoid arthritis (RA) remains imprecise, particularly early in the course of the disease.

Up to now, rheumatoid factor (RF) has been used as a typical marker for RA; however, RF has a low specificity because it also occurs in many inflammatory diseases as well as in healthy people. It has recently been shown that autoantibodies directed toward cyclic citrullinated peptides (anti-CCP) are potentially important serological markers for diagnosis and prognosis in RA. ${ }^{1}$

The proteolytic pathways associated with cellular interactions also seem to have an important role in joint cartilage destruction of RA. Matrix metalloproteinase-3 (MMP-3) is secreted by fibroblasts and synovial cells, ${ }^{2}$ and it has been shown to be increased in RA serum, not only in the late stage but also in the early stage of the disease. Therefore, MMP-3 is a useful marker for predicting bone damage in early RA. ${ }^{3}$

In many early cases of RA, patients will not always fulfil the American College of Rheumatology criteria. Therefore, it is important to detect the point at which disease-specific autoantibodies and proteinases appear in RA serum. In this study we directly investigated the production of anti-CCP and MMP-3 using a severe combined immunodeficiency (SCID) mutant mouse, into which human RA synovial tissue was transferred.

SCID mice are a well known model for analysing the developmental mechanism of $\mathrm{T}$ and $\mathrm{B}$ cells. We previously developed SCID mice (CB.17/Icr; Charles River Japan, Tokyo, Japan) in which human RA synovial tissue was grafted (SCID-HuRAg), and we evaluated them as models for RA. ${ }^{4}$ The histological features of RA were observed in all SCIDHuRAg mice and these mice induced the production of human antibodies. Proliferative synovial fibroblasts and infiltration of inflammatory cells were also seen in the pannus.

The serum levels of anti-CCP and human MMP-3 of SCIDHuRAg mice were examined weekly after implantation. Nonimplanted SCID mice sera were used as controls. Figure 1 shows representative results of independent experiments from two patients. The mean (SD) anti-CCP and MMP-3 levels in the serum of the patients were $702(26.9) \mathrm{U} / \mathrm{ml}$ and 321 (12.0) ng/ml, respectively. Human, not mouse, MMP-3 appeared in mouse serum shortly after implantation and decreased immediately. On the other hand, anti-CCP increased gradually and reached a plateau from the fifth week. It is reported that anti-CCP are produced locally in the inflamed synovial tissue from RA. ${ }^{67}$ Therefore we think it is reasonable that the surviving, activated human $\mathrm{B}$ cells can produce autoantibodies, and the proliferative synovial fibroblasts around the engrafted tissue can produce MMP-3, and that producing autoantibodies spontaneously takes much longer than inducing enzyme. In our previous report, both human RF and interleukin 6 were also detected in these mice sera $^{4}$ and not in mice with tissue implants from osteoarthritis synovia (data not shown).

MRL-lpr/lpr mice develop an autoimmune syndrome resembling human systemic lupus erythematosus. ${ }^{8}$ Anti$\mathrm{CCP}$ were present in these mice and $(\mathrm{NZW} \times \mathrm{B} 6) \mathrm{F}_{1}$-hbcl-2 transgenic mice, which have defects in the regulation of B cell apoptosis. ${ }^{9}$ However, these animals showed not only antibody reactivity against the citrullinated peptide $\mathrm{cfcl-cyc}$ peptide, but also against the non-citrullinated control peptide; therefore, Vossenaar et al reported that the antibodies in these mice are not citrulline specific, and citrulline-specific autoantibodies are present only in human patients with RA and not in animal models of autoimmune disease. ${ }^{10}$

We think that the main problem is that citrulline-specific autoantibodies detected by both groups were of mouse origin. On the contrary, all the target cells within SCID-HuRAg mice which we used were of human origin, having migrated from the implanted tissue, and anti-CCP and MMP-3 were of human origin, too.

In conclusion, we showed the point at which diseasespecific autoantibodies and proteinases appear in RA. SCIDHuRAg mice will be worth using in the study and development of new drugs for RA. 


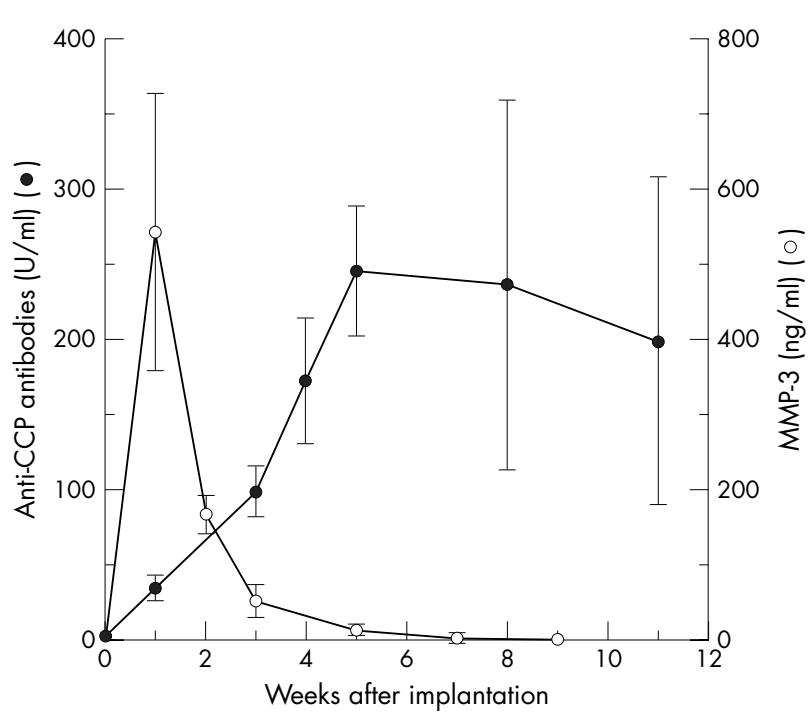

Figure 1 Time course of the serum levels of anti-CCP and MMP-3 in SCID-HuRAg mice. The results represent two independent experiments. The tissues from each of two patients were transferred to each of eight mice and each point represents a mean $(S D)$ value $(n=8)$. Anti-CCP antibodies were measured with a second generation anti-CCP enzyme linked immunosorbent assay (ELISA) kit (Immunoscan RA the anti-CCP Mark2 kit; Euro-Diagnostica, Arnhem, The Netherlands). The concentrations of MMP-3 in sera were determined by a one step sandwich ELISA system using a human MMP-3 kit (Panaclear MMP-3; Daiichi Pure Chemicals Co, Tokyo, Japan). Both assays were conducted according to the manufacturer's instructions. Their cut off values in human serum levels are $25 \mathrm{U} / \mathrm{ml}$ for anti-CCP and $29.0 \mathrm{ng} / \mathrm{ml}$ for MMP-3. Non-implanted SCID mice sera were used as controls (week 0).

\section{ACKNOWLEDGEMENTS}

Dr Iwaki-Egawa's work was supported, in part, by a grant from the Akiyama Foundation (Japan).

\section{Authors' affiliations}

S Iwaki-Egawa, Y Watanabe, Hokkaido College of Pharmacy, Otaru, Japan
H Matsuno, Toin University of Yokohama, Kanagawa, Japan Y Ogawa, Toyama Medical and Pharmaceutical University, Toyama, Japan

This study was approved by the ethics committee of Hokkaido College of Pharmacy.

Correspondence to: Dr S Iwaki-Egawa, Department of Pharmacy,

Hokkaido College of Pharmacy, 7-1 Katsuraoka-cho, Otaru 047-0264, Japan; sachiko@hokuyakudai.ac.jp

Accepted 16 December 2004

\section{REFERENCES}

1 Visser H, le Cessie S, Vos K, Breedveld FC, Hazes JM. How to diagnose rheumatoid arthritis early: a prediction model for persistent (erosive) arthritis. Arthritis Rheum 2002;46:357-65.

2 Okada Y, Nagase H, Harris E Jr. A metalloproteinase from human rheumatoid synovial fibroblasts that digests connective tissue matrix components. Purification and characterization. J Biol Chem 1986;261:14245-55.

3 Yamanaka H, Matsuda Y, Tanaka M, Sendo W, Nakajima H, Taniguchi A, et al. Serum matrix metalloproteinase 3 as a predictor of the degree of joint destruction during the six months after measurement, in patients with early rheumatoid arthritis. Arthritis Rheum 2000;43:852-8.

4 Matsuno H, Sawai T, Nezuka T, Uzuki M, Tsuji H, Nishimoto N, et al. Treatment of rheumatoid synovitis with anti-reshaping human interleukin-6 receptor monoclonal antibody: use of rheumatoid arthritis tissue implants in the SCID mouse model. Arthritis Rheum 1998;41:2014-21.

5 Sakai K, Matsuno H, Morita I, Nezuka T, Tsuji H, Shirai T, et al. Potential withdrawal of rheumatoid synovium by the induction of apoptosis using a novel in vivo model of rheumatoid arthritis. Arthritis Rheum 1998;41:1251-7.

6 Masson-Bessiere C, Sebbag M, Durieux JJ, Nogueira L, Vincent C, GirbalNeuhhauser $\mathrm{E}$, et al. In the rheumatoid pannus, anti-filaggrin autoantibodies are produced by local plasma cells and constitute a higher proportion of $\lg G$ than in synovial fluid and serum. Clin Exp Immunol 2000;119:544-52.

7 Vossenaar ER, Smeets TJM, Kraan MC, Raats JM, van Venrooij WJ, Tak PP. The presence of citrullinated proteins is not specific for rheumatoid synovial tissue. Arthritis Rheum 2004;50:3485-94.

8 Cohen PL, Eisenberg RA. Lpr and gld: single gene models of systemic autoimmunity and lymphoproliferative disease. Annu Rev Immunol 1991;9:243-69.

9 Ló pez-Hoyos M, Marquina R, Tamayo E, Gonzalez-Rojas J, Izui S, Merino R, et al. Defects in the regulation of $B$ cell apoptosis are required for the production of citrullinated peptide autoantibodies in mice. Arthritis Rheum 2003;48:2353-61.

10 Vossenaar ER, van Boekel MA, van Venrooii WJ, Lopez-Hoyoz M, Merino J, Merino $R$, et al. Absence of citrulline-specific autoantibodies in animal models of autoimmunity. Arthritis Rheum 2004;50:2370-2.

\title{
Absence of anti-cyclic citrullinated peptide antibodies in erosive osteoarthritis: further serological evidence of the disease as a subset of osteoarthritis
}

\author{
G Morozzi, F Bellisai, A Fioravanti, M Galeazzi
}

Ann Rheum Dis 2005;64:1095-1096. doi: 10.1136/ard.2004.030213

$\mathrm{E}$ rosive osteoarthritis (EOA) is considered to be a rare subset of osteoarthritis (OA) characterised by destructive changes involving the proximal interphalangeal and distal interphalangeal joints. ${ }^{1-3}$ Laboratory findings are usually negative even though a slight increase of erythrocyte sedimentation rate may occur. ${ }^{2}$ Radiologically, central erosions and the "gull wing" deformity characterise the disorder." Synovial pathology shows changes consistent with both rheumatoid arthritis (RA) and OA. ${ }^{12}$ Histological examination of synovium from patients with EOA joints shows lining cell hyperplasia, lymphocytic infiltration, and pannus formation, features indistinguishable from those of RA. ${ }^{1}$
The relationship between EOA and classical OA is controversial, as some authors consider it to be a separate disease entity, some regard it as one end of the spectrum of $\mathrm{OA}$, and some regard it as an interface between OA and RA. ${ }^{14}$ A relationship between EOA and RA was first suggested by Ehrlich, ${ }^{5}$ who noted the superimposition of clinical, laboratory, and imaging findings of RA in 62 of 170 patients initially diagnosed with EOA. Moreover, in the early stages of the disease, the differential diagnosis between EOA and other arthritis, such as RA or psoriatic arthritis, may pose a challenge, requiring a number of laboratory tests and investigations. $^{36-8}$ It is well known that anti-cyclic citrullinated 
Table 1 Characteristics of our patients and controls

\begin{tabular}{|c|c|c|c|c|c|c|}
\hline & No & $\begin{array}{l}\text { Age (years) } \\
\text { Mean (SD) }\end{array}$ & Sex & $\begin{array}{l}\text { Disease duration } \\
\text { (years) } \\
\text { Mean (SD) }\end{array}$ & $\begin{array}{l}\text { IgM RF positive } \\
\text { No }(\%)\end{array}$ & $\begin{array}{l}\text { IgG anti-CCP positive } \\
\text { No }(\%)\end{array}$ \\
\hline EOA & 32 & $59.3(11.4)$ & $26 \mathrm{~F} ; 6 \mathrm{M}$ & $8.3(3.6)$ & 0 & 0 \\
\hline NOA & 35 & $61.5(9.2)$ & $21 \mathrm{~F} ; 14 \mathrm{M}$ & $9.1(3.2)$ & 0 & 0 \\
\hline RA & 45 & $52(16)$ & $32 \mathrm{~F} ; 13 \mathrm{M}$ & $10.6(6.5)$ & $28(62)$ & 31 (69) \\
\hline Healthy subjects & 50 & $54.4(18.2)$ & $39 F ; 11 M$ & - & $2(4)$ & 0 \\
\hline
\end{tabular}

peptide antibodies (anti-CCP) are highly specific for RA and good predictors of radiographic joint damage'; for that reason this study aimed at detecting these autoantibodies in serum samples of patients with EOA, in order to ascertain their clinical usefulness and, possibly, to contribute to the clarification of the relationship of EOA with classical OA and RA. On the one hand, positive results may support the hypothesis that EOA is an interface between OA and RA, but, on the other hand, negative results may support the hypothesis that EOA is one end of the spectrum of OA.

We evaluated 32 patients with EOA showing typical EOA radiographic findings. ${ }^{6}$ The control group included 35 patients affected by nodal OA of the hands (NOA) fulfilling American College of Rheumatology criteria ${ }^{10}$ and 50 healthy subjects. All the patients were examined for exclusion of psoriatic arthritis, RA, undifferentiated spondyloarthropathies, gout, and pseudogout. In addition, 45 patients with RA were examined to test the sensitivity and specificity of our anti-CCP enzyme linked immunosorbent assay (ELISA) kit (table 1).

The second generation of anti-CCP antibodies was tested with an ELISA commercial kit (Axis-Shield, UK). All groups were assayed for IgM rheumatoid factor (RF), with ELISA methodology (Orgentec, Germany). Patients with EOA and the control group were negative for anti-CCP, whereas two healthy subjects were IgM RF positive. Of 45 patients with RA, 23 were positive for RF and anti-CCP, 5 for RF, 8 for antiCCP, and 9 negative for both. The specificity of anti-CCP in diagnosing RA is well known, ${ }^{9}$ and in our study it was $100 \%$. For this reason the detection of anti-CCP has a higher diagnostic performance than RF, by virtue of its higher specificity. The sensitivity of anti-CCP was $69 \%$, but becomes $80 \%$, if calculated in conjunction with RF.

In our opinion, the absence of anti-CCP antibodies in EOA as opposed to their high prevalence in RA is a further difference between EOA and RA, supporting the hypothesis that EOA represents a subset of OA, as suggested by other authors..$^{2-4} 7$ Therefore, the anti-CCP assay can be considered a further useful test to help to discriminate between EOA and
RA in the early stage of the disease. The conjunction of both a negative RF test and a negative anti-CCP test make the diagnosis of RA unlikely and argue for the diagnosis of EOA.

\section{Authors' affiliations}

G Morozzi, F Bellisai, A Fioravanti, M Galeazzi, Dipartimento di Medicina Clinica e Scienze Immunologiche, Sezione di Reumatologia, Università di Siena, Italia

Correspondence to: Dr G Morozzi, Dipartimento di Medicina Clinica e Scienze Immunologiche, Sezione di Reumatologia, Università di Siena, Policlinico Le Scotte, 53100 Siena, Italia; morozzi@unisi.it

Accepted 30 January 2005

\section{REFERENCES}

1 Peter JB, Pearson CM, Marmor L. Erosive osteoarthritis of the hands. Arthritis Rheum 1966;9:365-87.

2 Belhorn LR, Hess EV. Erosive osteoarthritis. Semin Arthritis Rheum, 1993;22:298-306.

3 Punzi L, Ramonda R, Sfriso P. Erosive osteoarthritis. Best Pract Res Clin Rheumatol 2004; 18:739-58.

4 Cobby M, Cushnagan J, Creamer P, Dieppe P, Watt I. Erosive osteoarthritis: is it a separate disease entity? Clin Radiol 1990:42:258-63.

5 Ehrlich GE. Inflammatory osteoarthritis. II. The superimposition of rheumatoid arthritis. J Chron Dis 1972;25:635-43.

6 Martel W, Stuck KJ, Dworin AM, Hylland RJ. Erosive osteoarthritis and psoriatic arthritis: a radiological comparison in the hand, wrist and feet. AJR Am J Roentgenol 1980;134:125-35.

7 Falsetti P, Frediani B, Fioravanti A, Acciai C, Baldi F, Filippou G, et al. Sonographic study of calcaneal entheses in erosive osteoarthritis, nodal osteoarthritis, rheumatoid arthritis and psoriatic arthritis. Scand J Rheumatol 2003;32:229-34.

8 Fioravanti A, Tofi C, Cerase A, Priolo F, Marcolongo R. Capillaroscopic findings in erosive and nodal osteoarthritis of the hands. Clin Rheumatol 2001;20:174-6.

9 Meyer O, Labarre C, Dougados M, Goupille Ph, Cantagrel A, Dubois A, et al. Anticitrullinated protein/peptide antibody assay in early rheumatoid arthritis for predicting five year radiographic damage. Ann Rheum Dis 2003:62:120-6.

10 Altman R, Alarcon G, Appelrouth D, Bloch D, Borenstein D, Brandt K, et al. The American College of Rheumatology criteria for the classification and reporting of osteoarthritis of the hand. Arthritis Rheum 1990;33:1601-10.

\title{
Paternal and maternal exposure to leflunomide: pregnancy and neonatal outcome
}

\author{
M De Santis, G Straface, A Cavaliere, B Carducci, A Caruso
}

Ann Rheum Dis 2005;64:1096-1097. doi: 10.1136/ard.2004.030254

eflunomide is a pyrimidine synthesis inhibitor with proven teratogenic and fetotoxic effects in animal studies, and its active metabolite is detectable in plasma up to 2 years after discontinuation of the drug. ${ }^{1-3}$ For this reason the fetus could have in utero exposure to leflunomide up to 2 years after the end of treatment unless an oral cholestyramine regimen, $8 \mathrm{~g}$ three times daily for 11 days, is administered to obtain undetectable plasmatic levels. ${ }^{1-3}$ 


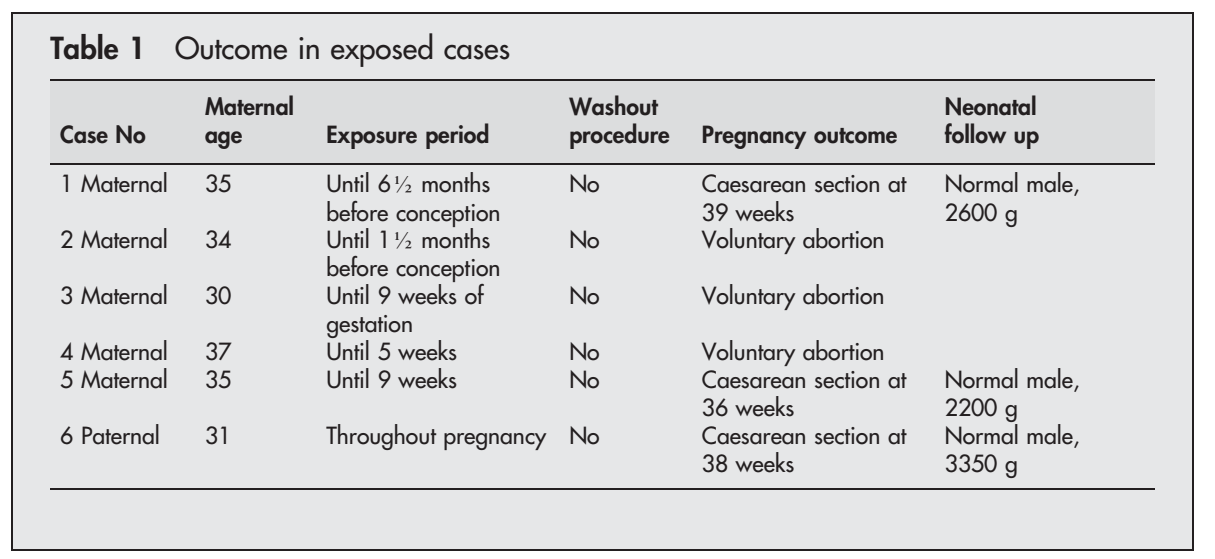

Leflunomide has been classified as pregnancy category $\mathrm{X}$ by the Federal Drug Administration and the manufacturer recommends that for women of childbearing age "treatment with leflunomide must not be started until pregnancy is excluded and it has been confirmed that reliable contraception is being used". ${ }^{14}$ Label instructions about paternal exposure recommend a washout procedure to minimise any possible risk. ${ }^{1}$ To date, there have been no epidemiological human studies of pregnancies after or during paternal or maternal leflunomide exposure, and current knowledge is restricted to a few cases. ${ }^{24}$

\section{CASE REPORTS}

We report on five cases of women who conceived within 2 years after the discontinuation of, or during, leflunomide treatment, and one case of pregnancy during paternal exposure (table 1). They were referred to our teratogen information service between July 2002 and January 2004.

Four women were exposed in the first trimester and one conceived $6 \frac{1}{2}$ months after stopping the treatment. Despite our recommendation, none of the women performed the washout procedure, resulting, therefore, in fetal exposure to therapeutic drug levels during organogenesis. In the case of paternal exposure, leflunomide was taken from 6 months before conception and during the whole pregnancy with intercourse without a condom during the gestation.

Three women had voluntary abortions owing to the fear of malformation and three women had live births with healthy babies (two maternal and one paternal exposure). In one of the two cases of maternal exposure the leflunomide treatment was given until $6 \frac{1}{2}$ months before the conception, in the other until the 9 th week of gestation. They delivered their babies at 39 and 36 weeks, both by caesarean section, weighing 2600 and 2200 g respectively, with normal neonatal outcome. These cases increase the number of previously reported cases, bringing to four the number of live birth normal babies with complete follow up. To date there has been no report of human congenital malformation after prenatal leflunomide exposure. In the case of paternal treatment, a normal baby of $3350 \mathrm{~g}$ was delivered by caesarean section at 38 weeks-the first reported case.

\section{DISCUSSION}

Seven cases of babies born with congenital malformations were reported by Ostensen referring to a manufacturer's safety update to 2003 about 164 pregnancies followed up completely in 310 women exposed. Of these 164 cases, 85 were full term pregnancies, 43 were voluntary abortions, and 36 miscarried. $^{5}$
Chakravarty et al reported 10 pregnancies in patients taking leflunomide: two cases lost at follow up, two continuing pregnancies, two legal abortions, one spontaneous abortion, two full term healthy babies, and one preterm infant without detailed follow up. ${ }^{4}$

The scarcity of published data about human pregnancy and neonatal outcome justifies the collection of as many cases as possible because in teratological counselling it is mandatory to consider all known human cases once a drug has been indicated as a potential teratogen in experimental studies. A post-marketing surveillance study has been established by the manufacturer to monitor the outcome of pregnancies, including first trimester exposures. ${ }^{2}{ }^{6}$

At present the possible fetal and neonatal side effects of leflunomide exposure are being investigated by a Canadian OTIS (Organisation of Teratology Information Service) in a prospective study. ${ }^{5}$

We consider it advisable to warn couples that no controlled or adequate study is available and for inadvertent exposure during pregnancy it is necessary to inform them about the theoretical reproductive risk reported in animal studies and to recommend the washout procedure and accurate fetal ultrasound examinations.

\section{Authors' affiliations}

M De Santis, G Straface, A Cavaliere, B Carducci, A Caruso, Telefono Rosso-Teratology Information Service. Department of Obstetrics and Gynaecology, Catholic University of the Sacred Heart, Rome, Italy

Correspondence to: DrM De Santis, Telefono Rosso-Teratology Information Service, Department of Obstetrics and Gynaecology, Catholic University of the Sacred Heart, Largo A Gemelli, 800168 Rome, Italy; marcodesantis@rm.unicatt.it

Accepted 21 November 2004

\section{REFERENCES}

1 Arava Prescribing Information. Available on-line at http://www.aventisus.com/Pls/arava_TXT.html, accessed 9 March, 2005.

2 Brent RL. Teratogen update: reproductive risks of leflunomide (Arava); a pyrimidine synthesis inhibitor: counseling women taking leflunomide before or during pregnancy and men taking leflunomide who are contemplating fathering a child. Teratology $2001 ; 63: 106-12$.

3 Arava Consumer Information. Available on-line at http:www.fda.gov/cder/ consumerinfo/default.htm, accessed 18 March 2005.

4 Chakravarty EF, Sanchez-Yamamoto D, Bush TM. The use of disease modifying antirheumatic drugs in women with rheumatoid arthritis of childbearing age: a survey of practice patterns and pregnancy outcomes. J Rheumatol 2003;30:241-6.

5 Ostensen $M$. Disease specific problems related to drug therapy in pregnancy. Lupus 2004; 13:746-50.

6 Lyons Jones K, Johnson DL, Chambers CD. Monitoring leflunomide (Arava) as a new potential teratogen. Teratology 2002;65:200-2. 


\title{
Spontaneous remission of marginal zone B cell lymphoma in a patient with seropositive rheumatoid arthritis after discontinuation of infliximab-methotrexate treatment
}

\author{
R Thonhofer, M Gaugg, M Kriessmayr, H J Neumann, L Erlacher
}

Ann Rheum Dis 2005;64:1098-1099. doi: 10.1136/ard.2004.026252

A 64 year old female patient with seropositive rheumatoid arthritis (RA) diagnosed in 1997 was referred to our hospital in March 2002, because of high disease activity despite methotrexate (MTX)-sulfasalazine treatment. After exclusion of contraindications infliximab treatment in combination with MTX was started, with good response. At clinical control before the 16th infliximab infusion the patient reported problems with her sinuses. In a computed tomography (CT) scan of that region reactive lymphatic tissue was suspected. Because of the small size (3.5 to $2.8 \mathrm{~cm}$ ) of the lesion, lymphoma or hypopharynx carcinoma was ruled out. Despite the benign features of the lesion a biopsy was performed, because of the increased risk of malignancy in $\mathrm{RA}^{1-3}$ during disease modifying antirheumatic drug (DMARD) treatment. ${ }^{45}$ Histopathological evaluation and immunohistochemistry led to the diagnosis of an extranodal marginal zone B cell lymphoma of the MALT type. The DMARD treatment was immediately discontinued.

Magnetic resonance imaging (MRI) of the head and neck, CT scans of the thorax and abdomen, ultrasound examination of the abdomen and groin, ileocolonoscopy, and gastroduodenoscopy were unremarkable. Biopsies of the stomach showed Helicobacter pylori infection, which was treated according to the recommendations of Mantzaris et al. ${ }^{6}$ In bone marrow examinations no evidence of lymphoma infiltration was detected. Signs of Sjögren's syndrome were not present.

After consultation of oncologists we decided not to start antineoplastic treatment. We agreed on monthly clinical and laboratory controls. The MRI scan of the head and neck carried out 3 and 6 months after primary diagnosis of the lymphoma showed no evidence of a tumour. Biopsy specimens taken again from the region of interest showed no evidence of lymphoma infiltration. We interpreted the available findings as remission of the lymphoma.

\section{DISCUSSION}

Patients with RA are at increased risk of lymphoproliferative disease. ${ }^{1-3}$ The risk is even higher in patients with increased inflammatory activity. ${ }^{3}$ A proportion of RA associated lymphomas have been attributed to the immunosuppressive effects of DMARDs. ${ }^{45}$

In the case of our patient both risk factors for lymphoma development, high inflammatory activity and DMARD treatment, were present. The patient was treated with MTX for 350 weeks and during that time 4975 mg MTX was ingested. The total dose of infliximab given was $5100 \mathrm{mg}$. It is unlikely that the marginal zone lymphoma had coexisted for a long time with treatment because of its small size. In addition, reports of the fulminant course of lymphomas after initiating a tumour necrosis factor $\alpha$ antagonist treatment have been published. ${ }^{8}$

Our strategy of waiting and watching after discontinuation of infliximab MTX treatment was based on the low malignant potential of this type of lymphoma and reported findings. ${ }^{58}$

We conclude that in our patient DMARD treatment most probably was responsible for induction of the lymphoma, because complete remission occurred 3 months after stopping the antirheumatic drugs.

There was no difference in steroidal and non-steroidal antiinflammatory drug use before and after diagnosis of the marginal zone B cell lymphoma, so these drugs are unlikely to have been responsible for the lymphoma remission.

Active RA is a risk factor for lymphoma development. In the follow up of our patient we recorded raised inflammatory activity after discontinuation of DMARD treatment. If disease activity is mainly responsible for the development of the lymphoma, it seems to be unlikely that remission would be achieved during phases of high inflammatory activity.

Discussion continues as to whether a monoclonal expansion of B memory lymphocytes is an inflammatory response to an infectious agent, or a real tumour formation. ${ }^{9}$ According to published reports the eradication of $H$ pylori infection may induce lymphoma regression. ${ }^{10}$ However, when all the risk factors in the case of our patient are taken into account, it seems unlikely that antibiotic treatment contributed significantly to remission of the lymphoma.

For clinical routine in cases like ours we recommend that drugs should be withdrawn and the patient monitored closely for evidence of lymphoma regression before initiating specific treatment.

\section{ACKNOWLEDGEMENTS}

This report was supported by Forschungsverein Innere Medizin Klagenfurt.

\section{Authors' affiliations}

R Thonhofer, M Gaugg, M Kriessmayr, L Erlacher, Allgemein öffentliches Krankenhaus der Elisabethinen Klagenfurt GmbH, 9020 Klagenfurt, Austria

H J Neumann, Krankenhaus der Barmherzigen Brüder, 9300 Sankt Veit an der Glan, Austria

Correspondence to: Dr R Thonhofer, Allgemein öffentliches Krankenhaus der Elisabethinen Klagenfurt GmbH, Völkermarkterstrasse 15-19, 9020 Klagenfurt, Austria; rene.thonhofer@ekh.at

Accepted 28 December 2004

\section{REFERENCES}

1 Kamel OW, van de Rijn M, Hanasono MM, Warnke RA. Immunosuppressionassociated lymphoproliferative disorders in rheumatic patients. Leuk Lymphoma 1995;6:363-8.

2 Georgescu L, Quinn G, Schwartzman S, Paget SA. Lymphoma in patients with rheumatoid arthritis: association with the disease state or methotrexate treatment. Semin Arthrits Rheum 1997;26: 794-8114. 
3 Thomas E, Brewster DH, Black RJ, Macfarlane GJ. Risk of malignancy among patients with rheumatic conditions. Int J Cancer 2000;88: 497-502.

4 Hazleman B. Incidence of neoplasms in patients with rheumatoid arthritis exposed to different treatment regimens. Am J Med 1985;78:39-43.

5 Georgescu L, Paget SA. Lymphoma in patients with rheumatoid arthritis: what is the evidence of a link with methotrexate? Drug Safety 1999:20:475-87.

6 Mantzaris GJ, Petraki K, Archavlis E, Amberiadis P, Christoforidis P, Kourtessas D, et al. Omeprazole triple therapy versus omeprazole quadruple therapy for healing duodenal ulcer and eradication of Helicobacter pylori infection: a 24-month follow-up study. Eur J Gastroenterol Hepatol 2002; 14:1237-43.
7 Wolfe F. Inflammatory activity but not methotrexate or prednisone predicts non-Hodgkin's lymphoma in rheumatoid arthritis: a 25-year study of 1767 RA patients [abstract]. Arthritis Rheum 1998:41(suppl):S188.

8 Brown LS, Greene MH, Sharon K, Gershon K, Edwards ET, Braun MM. Tumor necrosis factor antagonist therapy and lymphoma development. Arthritis Rheum 2002;46:3151-8.

9 Seto M. Genetic and epigenetic factors involved in B-cell lymphomagenesis. Cancer Sci 2004;95:704-10.

10 Dohden K, Kaizaki Y, Hosokawa O, Hayashi H, Hattori M. Regression of rectal mucosa-associated lymphoid tissue lymphoma but persistence of Helicobacter pylori infection of gastric mucosa after administration of lefloxacin: report of a case. Dis Colon Rectum 2004;47:1544-6.

\section{Anti-CD20 monoclonal antibody (rituximab) as an adjunct in the treatment of giant cell arteritis}

\section{A Bhatia, P J Ell, J C W Edwards}

W describe a patient with polymyalgia rheumatica/ giant cell arteritis (PMR/GCA) whose disease was refractory to a reduction in the dose of her glucocorticoid to an acceptable level. Our patient improved after B lymphocyte depletion but developed respiratory problems. To our knowledge this is the first description of such a case.

\section{CASE REPORT}

An 82 year old woman presented with a 4 week history of symptoms consistent with GCA of the temporal arteries and PMR. Of significance in her past medical history she had significant chronic airflow limitation with an $\mathrm{FEV}_{1} / \mathrm{FVC}$ (forced expiratory volume in 1 second/forced vital capacity) of $0.7 / 1.2$. Computed tomography of her chest identified a small area of bronchiectasis in the left lower lobe of her chest.

Her erythrocyte sedimentation rate (ESR) and $\mathrm{C}$ reactive protein (CRP) were, $109 \mathrm{~mm} / \mathrm{lst} \mathrm{h}$ (normal l-20) and $230 \mathrm{mg} / \mathrm{l}$ (normal 0-5.0), respectively. Treatment was started with $50 \mathrm{mg}$ of prednisolone. Three weeks later the patient developed a nasal left upper visual field defect. The dose of prednisolone was gradually reduced over the next 5 months.

She was, however, experiencing side effects of her prednisolone treatment, including weight gain, proximal muscle weakness, and the development of a cushingoid face. However, at a dose of $15 \mathrm{mg}$ of prednisolone a day, her symptoms of GCA returned with an increase of the ESR to $53 \mathrm{~mm} / \mathrm{lst} \mathrm{h}$. Azathioprine $100 \mathrm{mg} /$ day was not tolerated. Four months later while receiving $15 \mathrm{mg}$ of prednisolone her GCA again became symptomatic with transient visual changes including flashes of light. Her CRP rose to $92 \mathrm{mg} / \mathrm{l}$.

At this stage her GCA was not adequately treated and a decision to use B lymphocyte depletion therapy was made. Intravenous cyclophosphamide $(500 \mathrm{mg})$ with mesna followed by a single infusion of $\mathrm{l} g$ rituximab preceded by $100 \mathrm{mg}$ of methylprednisolone intravenously was given. An absolute CD19 count 1 month after treatment was $0.00 / 1$, confirming that B lymphocyte depletion had been successful.

Fluorodeoxyglucose positron emission tomography (FDGPET) undertaken before B lymphocyte depletion and $4 \frac{1}{2}$ months after treatment provides objective confirmation of her arteritis and demonstrates her response to $B$ lymphocyte depletion (fig 1). After B lymphocyte depletion the patient's symptoms also resolved and her CRP returned to normal. Six months after B cell depletion our patient has no symptoms suggestive of GCA. Her ESR is currently $13 \mathrm{~mm} /$ lst $\mathrm{h}$ and her CRP $6.0 \mathrm{mg} / \mathrm{l}$.

Four days after B lymphocyte depletion our patient developed respiratory failure and was transferred to the intensive therapy unit. A chest radiograph showed lobar consolidation bilaterally, the cause of which remains unclear but may be a result of treatment with rituximab. Her chronic airflow limitation remains a major constraint on her mobility and she has until now required 24 hour domiciliary oxygen $(2 \mathrm{l} / \mathrm{min})$.

\section{DISCUSSION}

Our patient's GCA was inadequately controlled with a dose of prednisolone of 20-30 mg and treatment was associated with significant side effects. An alternative treatment is needed in such cases.

The aetiology of PMR/GCA is unclear, but muscle biopsy specimens from patients with PMR show immunoglobulin deposits around fascicles, ${ }^{1}$ and serum samples from patients with PMR have been found to contain immune complexes. ${ }^{2}$ These features suggest that PMR/GCA may be mediated by a particular type of small immune complex. We have previously suggested that binding of such complexes to matrix bound Fc $\gamma$ RIIIa on fibrillin based microfibrils in muscles and in the internal elastic lamina of arteries may initiate local disease which will lead to symptoms associated with PMR and GCA. ${ }^{3}$

Taken together with overlapping clinical and immunogenetic features (HLA-DR4) this suggests that PMR/GCA might respond to new treatments being developed for RA.

B lymphocyte depletion treatment has recently proved successful in rheumatoid arthritis. ${ }^{4}$ On the basis of inadequate control of the GCA and the above theoretical considerations, a decision was made to treat this patient . Our patient's favourable response suggests that this approach to the management of patients with GCA may be worthy of further investigation.

A significant number of lower respiratory tract infections have occurred in our cohort of patients with rheumatoid arthritis treated with B cell depletion (125 cycles) at University College London. ${ }^{5}$

This case illustrates the possible risk that B cell depletion may pose in patients with marginal respiratory reserve.

\section{Authors' affiliations}

A Bhatia, J C W Edwards, Department of Rheumatology, University College London Hospitals, Arthur Stanley House, 40-50 Tottenham Street, London WIT 4NJ, UK 

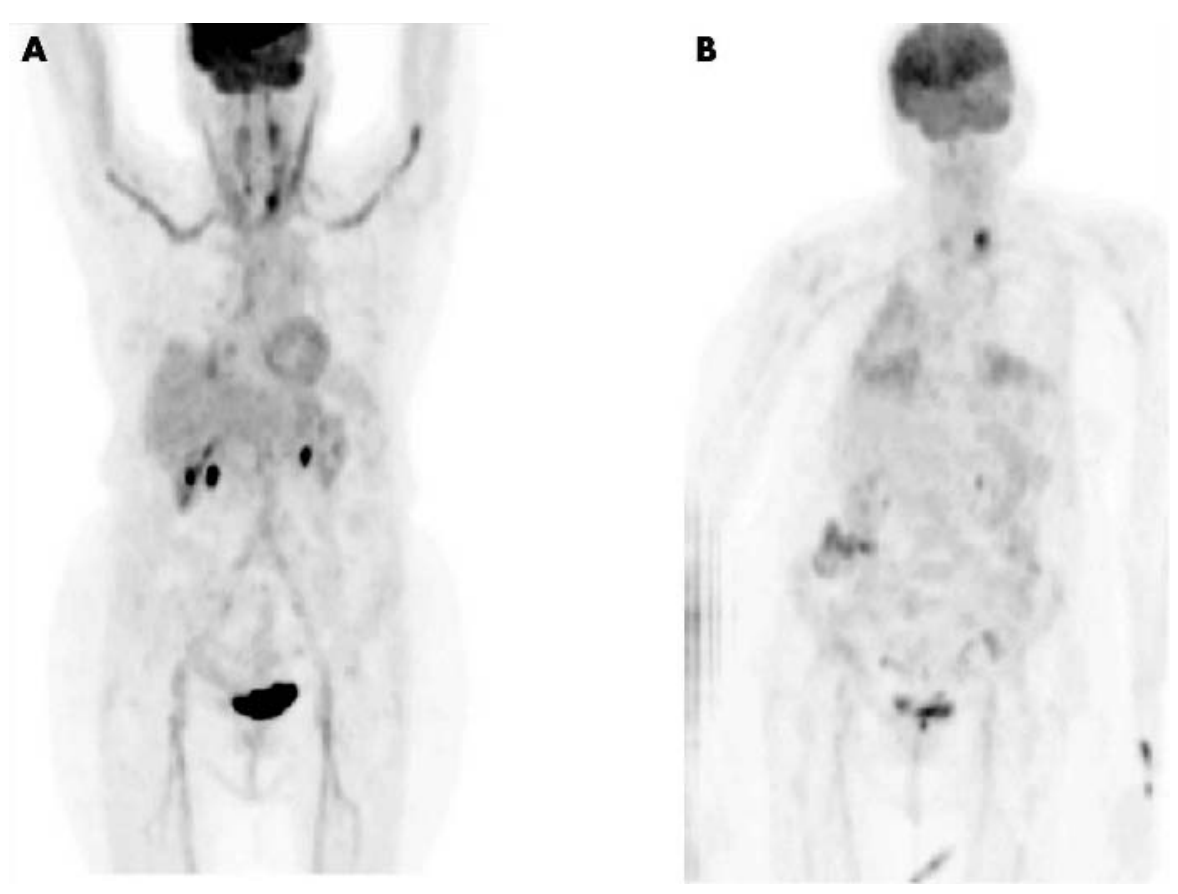

Figure 1 (A) FDG-PET before B lymphocyte depletion shows significant vascular uptake of FDG in both external carotid and subclavian arteries. Part of the abdominal aorta and both iliac arteries also show increased vascular FDG uptake. (B) FDG-PET $41 \frac{1}{2}$ months after treatment shows a reduction of vascular uptake with no uptake in the iliac vessels or ascending aorta.

P J Ell, Institute of Nuclear Medicine, University College London Hospitals, Middlesex Hospital, Mortimer Street, London WIT 3AA, UK

Correspondence to: Professor J CW Edwards; jo.edwards@ucl.ac.uk Accepted 18 April 2005

\section{REFERENCES}

1 Shintani S, Tsuruoka S, Takami M, Mihara N, Shiigai T, Kikuchi M. Immunofluorescence study of immune complexes in polymyalgia rheumatica. J Neurol Sci 1995; 128:103-6.
2 Smith AJ, Kyle V, Cawston TE, Hazleman BL. Isolation and analysis of immune complexes from sera of patients with polymyalgia rheumatica and giant cell arteritis. Ann Rheum Dis 1987;46:468-74.

3 Blades S, Bhatia A, Kielty C, Edwards J. Immunoregulatory molecules bound to microfibrils:a clue to the link between polymyalgia and rheumatoid arthritis. Rheumatology (Oxford) 1998;37(suppl 1):35.

4 Edwards JCW, Szczepanski L, Szechinski J, Filipowicz-Sosnowska A, Emery P, Close DR, et al. Efficacy of B cell-targeted therapy with rituximab in patients with rheumatoid arthritis. N Eng J Med 2004;350:2572-81

5 Edwards JCW, Leandro M, Cambridge G. B lymphocyte depletion therapy with rituximab in rheumatoid arthritis. Rheum Dis Clin North Am 2004;30:393-403 